\title{
PP2A and tumor radiotherapy
}

\author{
Xiao Lei ${ }^{\dagger}, \mathrm{Na} \mathrm{Ma}{ }^{\dagger}$, Lehui Dư, Yanjie Liang, Pei Zhang, Yanan Han and Baolin Qu* (i)
}

\begin{abstract}
Protein phosphatase 2A (PP2A) is a serine/threonine phosphatase that serves as a key regulator of cellular physiology in the context of apoptosis, mitosis, and DNA damage responses. Canonically, PP2A functions as a tumor suppressor gene. However, recent evidence suggests that inhibiting PP2A activity in tumor cells may represent a viable approach to enhancing tumor sensitivity to chemoradiotherapy as such inhibition can cause cells to enter a disordered mitotic state that renders them more susceptible to cell death. Indeed, there is evidence that inhibiting PP2A can slow tumor growth following radiotherapy in a range of cancer types including ovarian cancer, liver cancer, malignant glioma, pancreatic cancer, and nasopharyngeal carcinoma. In the present review, we discuss current understanding of the role of PP2A in tumor radiotherapy and the potential mechanisms whereby it may influence this process.
\end{abstract}

Keywords: Protein phosphatase 2A, Conventional tumor radiotherapy, DNA damage response, Radiosensitization effects

\section{Introduction}

While mainstays of tumor treatment efforts, conventional radiotherapy and chemotherapy often yield unsatisfactory therapeutic outcomes [1-3]. These poor outcomes are generally linked to tumor cell multidrug resistance and resistance to ionizing radiation [4-6]. In addition, while these treatments are well-tailored to killing rapidly proliferating tumor cells, they generally fail to impact hypoxic and quiescent cells, ultimately resulting in treatment failure and tumor recurrence [7-9]. Understanding the mechanistic basis for tumor cell chemoresistance and radioresistance is thus vital. Interestingly, recent research evidence suggests that radiosensitization can be achieved by accelerating cell cycle progression in quiescent cells such that they become proliferative $[10,11]$. Inhibiting proteins such as PP2A can drive quiescent tumor cells to enter mitosis, in turn potentially increasing tumor cell sensitivity to treatment $[12,13]$. Inhibiting $\mathrm{PP} 2 \mathrm{~A}$ may therefore represent a

\footnotetext{
* Correspondence: baolinqu301@163.com

${ }^{+}$Xiao Lei, Na Ma and Lehui Du contributed equally to this work. The First Medical Center of Chinese PLA General Hospital, Department of Radiation Oncology, Beijing, P. R. China
}

valuable new approach to promoting tumor radiosensitization. In the present review, we discuss current research progress pertaining to the role of PP2A in the context of tumor radiotherapy.

\section{The role of PP2A in radiation therapy}

PP2A is a serine/threonine phosphatase that functions as a tumor suppressor gene [14]. It is a complex composed of a core enzyme and a regulatory subunit. The core enzyme (PP2AD) is a dimer comprised of a $36 \mathrm{kD}$ catalytic subunit (PP2A c) and a $65 \mathrm{kD}$ regulatory subunit (PR65 or subunit A). PP2A has three subunits, including subunit $A$ and two subtypes of subunit $C(\alpha$ and $\beta$ ), with each of these subunits exhibiting distinct structural and catalytic activities. There are also multiple subtypes of subunit $\mathrm{B}$ that serve to control the specificity and localization of PP2A. Overall, there are four families of regulatory $B$ subunits capable of binding to the core enzyme: B (PR55), B' (B56 or PR61), B“ (PR72), and B" (PR93/PR110) [15-17]. Early research suggested that PP2A functions as a classic tumor suppressor gene that is downregulated or nonfunctional in many tumor types including lung, skin, breast, brain, ovarian, cervical, and

(c) The Author(s). 2020 Open Access This article is licensed under a Creative Commons Attribution 4.0 International License, which permits use, sharing, adaptation, distribution and reproduction in any medium or format, as long as you give appropriate credit to the original author(s) and the source, provide a link to the Creative Commons licence, and indicate if changes were made. The images or other third party material in this article are included in the article's Creative Commons licence, unless indicated otherwise in a credit line to the material. If material is not included in the article's Creative Commons licence and your intended use is not permitted by statutory regulation or exceeds the permitted use, you will need to obtain permission directly from the copyright holder. To view a copy of this licence, visit http://creativecommons.org/licenses/by/4.0/ The Creative Commons Public Domain Dedication waiver (http://creativecommons.org/publicdomain/zero/1.0/) applies to the data made available in this article, unless otherwise stated in a credit line to the data. 
colon cancers [18-20]. At a functional level, PP2A inhibits a range of tumor signaling pathways [21], preventing IL-2-induced JAK3 and STAT5 activation, which is normally dysregulated in many malignancies [22]. PP2A can also interact with the ERK2/MEK and Ras/Raf signaling pathways through direct and indirect mechanisms so as to control their activation. Given that constitutive Ras/ Raf/MEK/ERK signaling is a characteristic of many malignant tumor cells [23-26], these highlights another mechanism whereby PP2A can control oncogenesis. PP2A can also mediate proteasome dephosphorization and thereby impact c-Myc, which is often constitutively active in the context of tumorigenic transformation [27, 28].

Tumor metastasis, recurrence, and radioresistance all represent major roadblocks to the effective treatment of cancer patients $[29,30]$. Following PP2A inhibition, many tumors exhibit slower growth, increased apoptotic cell death, and greater sensitivity to ionizing radiation, as has been observed in the context of nasopharyngeal carcinoma, ovarian cancer, pancreatic cancer, liver cancer, and malignant glioma [31-35]. In malignant glioma, for example, PP2A inhibition increases the frequency of cells in the $M$ phase of mitosis, inhibiting tumor proliferation while driving increased radiosensitivity [31]. Similarly, PP2A inhibition in nasopharyngeal carcinoma has been linked to significant increases in the frequency of apoptotic cells and G2/M arrest [36]. Likewise, inhibiting PP2A in cancer significantly delayed DMA damage repair and thereby facilitated more rapid cell death following irradiation [37].

\section{Potential mechanisms whereby PP2A influences radiotherapy outcomes \\ The role of PP2A in mitosis}

PP2A is a key regulator of normal mitotic processes [38]. Greatwall kinase inhibited PP2A by small proteins ENSA and ARPP19, thereby attenuating PP2A-regulated Cdk1 dephosphorylation and promoting mitosis, whereas severe mitotic defects occur in the absence of greatwall kinase $[39,40]$. PP2A also negatively regulates Cdk1 activity via activating wee $1 /$ myt1 and by inhibiting cdc 25 [41]. Inhibiting PP2A can also drive the upregulation of molecules downstream of $\mathrm{Cdk} 1$, thereby promoting mitosis. This greatwall kinase/PP2A signaling pathway is thought to be a primary regulator of normal Cdk1 functionality in the context of mitosis [42]. PP2A can also act on other mitotic mediators such as the mitosis-specific kinases PLK1, which is a key marker of G2/M phase arrest following PP2A inhibition and which interacts with centrosomes during mitosis $[43,44]$. PP2A is also involved in the negative feedback inhibition of PLK1 and Aurora B, thereby regulating the spindle collection checkpoint in order to ensure that microtubules are properly connected to the centromere [45].

\section{Inhibiting PP2A causes G2/M cell cycle checkpoint inactivation and alters DNA damage repair}

Radiation-induced DNA damage can induce cell cycle arrest and DNA damage repair that is mediated by DNA damage checkpoint activation [46]. Irradiation-associated DNA damage can lead to G2/M checkpoint activation and consequent G2/M phase arrest, enabling DNA repair to occur prior to cellular entry into mitosis [47]. Cdc2/Cyclin $B$ is a key regulator of this $\mathrm{G} 2 / \mathrm{M}$ checkpoint, as $\mathrm{Cdc} 2 /$ Cyclin B activation is required in order for cells to proceed from the G2 phase into the cleavage phase [48]. DNA damage is rapidly followed by the phosphorylation and activation of the ATR and ATM kinases, which in turn activate Chk2 and Chk1 [49]. Chk2 and Chk1 function in part by suppressing the activation of $\mathrm{Cdc} 25$ family proteins such that $\mathrm{Cdc} 2 / \mathrm{Cyclin} \mathrm{B}$ activation is inhibited. Following DNA damage, Cdc2/Cyclin B activity is thus reduced, resulting in cell cycle arrest [50]. Following drug- or radiation-induced DNA damage, PP2A dephosphorylation can inhibit PLK1, which phosphorylates and activates Cdc25 and cyclins involved in the G2/M checkpoint, thereby facilitating cell cycle progression. PP2A may thus prevent cells from dividing by inhibiting PLK1 [44]. Moreover, inhibition of PP2A showed that radiation-induced inactivation of ATR and Chk1 kinase, phosphorylation of Cdc2-Tyr15, and inactivation of G2/M phase checkpoints, which attenuated radiation-induced G2/M arrest, thereby enabling tumor cells to enter into mitosis via reducing DNA damage repair efficiency and aggravating cellular mitotic disorders [51].

\section{Inhibiting PP2A promotes GO stage tumor cell entry into mitosis}

Cdk2 activity has recently been found to govern the proliferation of quiescent cells following mitosis, such that cells enter the G0 phase when Cdk2 activity levels are low. Regulating Cyclin E/Cdk2 activity at the end of the cell cycle can promote cellular proliferation [12]. In adult organisms, PP2A has been found to promote cellular quiescence [52]. In studies of Drosophila eyes and wings, researchers have determined that inhibiting PP2A at the end of the cell cycle can induce additional cell division and thereby impair such quiescence. In these Drosophila, the PP2A subunit B56 family member wdb serves as an important regulator of PP2A-related cellular quiescence. When PP2A activity is suppressed, cells that would normally enter the stationary phase instead exhibit robust Cdk2 activity [53]. Ectopic dominant testing has further revealed that abnormal Cyclin E/Cdk2 activity can promote additional cell cycle progression in the context of PP2A inhibition [12]. Reduced wdb/PP2A activity results in abnormally elevated Cyclin E levels, enabling quiescent cells to pass through the G0 phase and to thereby enter into mitosis [54], increasing cellular 
sensitivity to radiotherapy and chemotherapy. Given the important role of tumor cell quiescence as a driver of tumor radioresistance and recurrence in cancer patients [55], inhibiting PP2A may represent a viable means of promoting tumor radiosensitivity by driving cells in the G0 phase of the cell cycle to undergo mitosis.

\section{PP2A as a regulator of apoptosis}

PP2A can control apoptosis by influencing both PI3K/ Akt pathway signaling and the expression and activity of apoptosis-associated proteins [56]. In cells with functional Bcl-2, for example, PP2A has been shown to promote Bcl-2 dephosphorization and to thereby promote apoptotic cell death [57-59]. In contrast, in cells that are highly metabolically active, PP2A can dephosphorylate and thereby activate CaMKII so as to exert an antiapoptotic effect [60]. PP2A also modulates the P53 pathway such that it can activate Bax/Noxa/Puma and inhibit $\mathrm{Bcl}-2$ to drive apoptotic death [61-63].

In the context of the DNA damage response, the ATM signaling pathway directly activates and stabilizes PP2A by phosphorylating the ubiquitin ligase MDM2. PP2A in turn inhibits Akt1 pathway activity and thereby suppresses MDM2 activation, thus preventing the MDM2-mediated degradation of $\mathrm{p} 53$ [64]. In the presence of irreversible DNA damage, PP2A can also directly dephosphorylate p53, stabilizing this protein an inducing cell cycle arrest and apoptosis [65]. Inhibiting PP2A may therefore be a viable therapeutic strategy in highly metabolically active tumor cells. Suppressing PP2A activity in cells exhibiting DNA damage can also inhibit Bax expression and promote the cell cycle [65]. Studies of combination radiotherapy and PP2A inhibition have highlighted the consequent inhibition of interactions between $\mathrm{p} 53$ and PP2A, reducing the role of the 553 pathway in response to DNA damage and promoting cellular proliferation and $\mathrm{p} 53$-independent apoptotic cell death [66].

\section{PP2A as a regulator of the WNT/ $\beta$-catenin signaling pathway}

PP2A is capable of inhibiting WNT/ $\beta$-catenin signaling pathway activity [67], which normally plays important roles in governing the migration and proliferation of cells [68]. After WNT ligands interact with specific cell surface receptors, the Tcf family transcriptional coactivator $\beta$-catenin undergoes nuclear translocation, interacts with Tcf, and modulates target gene expression. This process often becomes constitutively activated during the early stages of oncogenesis [69]. In tumor cells in which the WNT signaling pathway is not active, cytoplasmic $\beta$-catenin is generally degraded. A complex composed of APC, DVL, Axin, and $\beta$-3-glycogen synthesis kinase can target $\beta$-catenin for degradation [31]. However, the PP2A-C regulatory subunit has also been shown to play downstream signaling roles in the context of the $\mathrm{WNT} / \beta$-catenin signaling pathway [70]. Aspirin has also been found to downregulate $\mathrm{WNT} / \beta$-catenin signaling pathway activity via inhibiting PP2A [71]. Positive PP2A feedback signaling has also been suggested to alter the $\mathrm{WNT} / \beta$-catenin signaling pathway in pancreatic cancer and colorectal cancer cell lines, thereby stabilizing the activation of this pathway $[72,73]$.

\section{Current clinical approaches to inhibiting PP2A as an approach to tumor radiosensitization}

To date, pharmacological inhibition of PP2A has largely been dependent upon the use of natural compounds such as okadaic acid and anthraquinone [74]. These compounds, however, exhibit varying degrees of toxicity. In contrast, LB100 is a water-soluble PP2A inhibitor that is less toxic than these other compounds. Research suggests that while radiotherapy can enhance PP2A activity, LB100 pretreatment prior to radiotherapy can suppress PP2A activation while simultaneously enhancing tumor sensitivity to irradiation [75]. LB100 has been leveraged in several clinical trials as a PP2A inhibitor owing to its efficacy and low toxicity [76]. In one study of pancreatic cancer, for example, LB100 was found to effectively radiosensitize pancreatic cancer cells without adversely affecting normal small intestinal cells [77]. LB100mediated PP2A inhibition has also been shown to prevent radiation-induced Rad51 foci formation and homologous recombination repair, thereby causing sustained DNA damage in cells following radiation exposure [77]. The presence of undifferentiated stem-like tumor cells capable of undergoing self-renewal is thought to be one of the key mechanisms underlying tumor recurrence and therapeutic resistance. Traditional radiotherapy and chemotherapy efforts are largely unable to impact these cancer step cells, as they grow slowly and are largely quiescent $[78,79]$. There is recent experimental evidence that the receptor co-repressor protein complex is a primary determinant of the stem-like properties of cancer stem cells in glioma tumors [80]. This receptor corepressor protein complex is composed of the receptor co-repressor protein, a deacetylase complex, steroids, hormone receptors, and transcription factors that function to control transcription in the context of glial differentiation [81]. Cytokine-induced ciliary neurotrophic factor stimulation of glioma precursor cells has been shown to inhibit receptor co-repressor protein complex activity via Akt/PI3K-mediated phosphorylation of the receptor co-repressor protein [82]. Inhibition of PP2A using LB100 resulted in enhanced Ak1 activity, thereby preventing receptor co-repressor protein complex formation and promoting cellular division, rendering quiescent tumor cells more sensitive to irradiation [31]. 


\section{Perspectives}

Inhibiting PP2A has been conclusively shown to enhance tumor cell radiosensitivity. However, further research is necessary in order to facilitate the optimal clinical implementation of these experimental findings. For example, while many studies have assessed the impact of inhibiting PP2A in tumor cells following radiation exposure, few studies have assessed the effect of such inhibition on normal tissues, which may also undergo potential radiosensitization [83-85]. Differences in PP2A expression profiles between normal and tumor tissues are also essential to ensure that tumor cells can be effectively killed without causing undue harm to healthy tissues. At present, there are also few specific inhibitors of PP2A available. To leverage the potential clinical utility of combination PP2A inhibition and radiotherapy treatment, it is vital that novel highly specific PP2A inhibitors be developed. The identification of specific inhibitors that preferentially target tumor cells while leaving healthy cells intact would further advance the clinical applications of PP2A inhibition. It is also important to note that many studies of PP2A inhibition have focused only on single factors [86-88], whereas tumor resistance and recurrence are multifactorial in nature. At present, there is a dearth of systematic or comprehensive studies pertaining to the mechanisms whereby PP2A inhibition bolsters the efficacy of radiation therapy.

\section{Conclusion}

In summary, inhibiting PP2A in combination with radiotherapeutic treatment may represent a viable approach to enhancing patient treatment outcomes and preventing tumor recurrence. However, further research regarding the mechanisms underlying such combination efficacy is still required. In addition, more specific pharmacological inhibitors of PP2A must be developed in order to achieve better clinical outcomes.

\section{Abbreviations}

PP2A: Protein phosphatase 2A; Cdk1: Cyclin Dependent Kinase 1; PLK1: pololike kinase 1; Cdc2: Cyclin Dependent Kinase 2; ATM: Ataxia telangiectasia mutated; ATR: ATM and RAD3-related; PI3K: Phosphoinositide 3-kinase; MDM2: Murine double minute-2; DNA: Deoxyribonucleic Acid; RNA: Ribonucleic Acid

\section{Acknowledgements}

Not applicable.

\section{Authors' contributions}

Xiao Lei and Na Ma designed the study and made the manuscript. Yanjie Liang did the perspective part. Yanan Han and Pei Zhang helped participate in the review design. Baolin Qu and Lehui Du participated in the writing of paper and revision of manuscript. All authors read and approved the final manuscript.

\section{Funding}

No funding was received.

\section{Availability of data and materials}

The datasets are available under reasonable request.

Ethics approval and consent to participate

Not applicable.

\section{Consent for publication}

Not applicable.

\section{Competing interests}

The authors declare that they have no competing interests.

Received: 3 July 2020 Accepted: 13 August 2020

Published online: 26 August 2020

\section{References}

1. Sun D, Chen J, Wang Y, Ji H, Peng R, Jin L, Wu W. Advances in refunctionalization of erythrocyte-based nanomedicine for enhancing cancer-targeted drug delivery. Theranostics. 2019;9:6885-900.

2. Verma $P$, Mittal $P$, Singh A, Singh IK. New entrants into clinical trials for targeted therapy of breast Cancer: an insight. Anti Cancer Agents Med Chem. 2019. https://doi.org/10.2174/1871520619666191018172926 [Epub ahead of print].

3. Dirksen U, Brennan B, Le Deley MC, Cozic N, van den Berg H, Bhadri V, Brichard B, Claude L, Craft A, Amler S, Gaspar N, Gelderblom H, Goldsby R, Gorlick R, Grier HE, Guinbretiere JM, Hauser P, Hjorth L, Janeway K, Juergens H, Judson I, Krailo M, Kruseova J, Kuehne T, Ladenstein R, Lervat C, Lessnick SL, Lewis I, Linassier C, Marec-Berard P, Marina N, Morland B, Pacquement H, Paulussen M, Randall RL, Ranft A, Le Teuff G, Wheatley K, Whelan J, Womer R, Oberlin O, Hawkins DS. High-Dose Chemotherapy Compared With Standard Chemotherapy and Lung Radiation in Ewing Sarcoma With Pulmonary Metastases: Results of the European Ewing Tumour Working Initiative of National Groups, 99 Trial and EWING 2008. J Clin Oncol. 2019;37:3192-202.

4. Tian LJ, Wu YP, Wang D, Zhou ZH, Xue SB, Zhang DY, Wei YG, Liu W. Upregulation of long noncoding RNA (InCRNA) X-inactive specific transcript (XIST) is associated with Cisplatin resistance in non-small cell lung Cancer (NSCLC) by Downregulating MicroRNA-144-3p. Med Sci Monit. 2019;25: 8095-104.

5. Wei L, Wang X, LV L, Liu J, Xing H, Song Y, Xie M, Lei T, Zhang N, Yang M. The emerging role of microRNAs and long noncoding RNAs in drug resistance of hepatocellular carcinoma. Mol Cancer. 2019;18.

6. Coliat P, Ramolu L, Jegu J, Gaiddon C, Jung AC, Pencreach E. Constitutive or induced HIF-2 addiction is involved in resistance to anti-EGFR treatment and radiation therapy in HNSCC. Cancers Basel. 2019;11.

7. Guerra-Rebollo M, Garrido C, Sanchez-Cid L, Soler-Botija C, Meca-Cortes O, Rubio N, Blanco J. Targeting of replicating CD133 and OCT4/SOX2 expressing glioma stem cells selects a cell population that reinitiates tumors upon release of therapeutic pressure. Sci Rep. 2019;9(1):9549.

8. Bi L, Xie C, Yao M, Thae Hnit SS, Vignarajan S, Wang Y, Wang Q, Xi Z, Xu H, Li Z, de Souza P, Tee A, Wong M, Liu T, Zhao X, Zhou J, Xu L, Dong Q. The histone chaperone complex FACT promotes proliferative switch of G0 cancer cells. Int J Cancer. 2019;145:164-78.

9. Luan RL, Wang PC, Yan MX, Chen J. Effect of lutein and doxorubicin combinatorial therapy on $\mathbf{S 1 8 0}$ cell proliferation and tumor growth. Eur Rev Med Pharmacol Sci. 2018:22:1514-20.

10. Sachdeva R, Wu M, Johnson K, Kim H, Celebre A, Shahzad U, Graham MS, Kessler JA, Chuang JH, Karamchandani J, Bredel M, Verhaak R, Das S. BMP signaling mediates glioma stem cell quiescence and confers treatment resistance in glioblastoma. Sci Rep. 2019;9.

11. Zhang J, Si J, Gan L, Di C, Xie Y, Sun C, Li H, Guo M, Zhang H. Research progress on therapeutic targeting of quiescent cancer cells. Artif Cells Nanomed Biotechnol. 2019;47:2810-20.

12. Sun D, Buttitta L. Protein phosphatase $2 A$ promotes the transition to $G 0$ during terminal differentiation in Drosophila. Development. 2015;142:3033-45.

13. Neviani P, Harb JG, Oaks JJ, Santhanam R, Walker CJ, Ellis JJ, Ferenchak G, Dorrance AM, Paisie CA, Eiring AM, Ma Y, Mao HC, Zhang B, Wunderlich M, May PC, Sun C, Saddoughi SA, Bielawski J, Blum W, Klisovic RB, Solt JA, Byrd JC, Volinia S, Cortes J, Huettner CS, Koschmieder S, Holyoake TL, Devine S, Caligiuri MA, Croce CM, Garzon R, Ogretmen B, Arlinghaus RB, Chen CS, Bittman R, Hokland P, Roy DC, Milojkovic D, Apperley J, Goldman JM, Reid A, Mulloy JC, Bhatia R, Marcucci G, Perrotti D. PP2A-activating drugs 
selectively eradicate TKl-resistant chronic myeloid leukemic stem cells. J Clin Invest 2013; 123: 4144-4157.

14. Shen F, Chen Y, Chen L, Qin J, Li Z, X J J. Amentoflavone promotes apoptosis in non-small-cell lung Cancer by modulating cancerous inhibitor of PP2A. Anat Rec Hoboken. 2019;302:2201-10.

15. Seshacharyulu P, Pandey P, Datta K, Batra SK Phosphatase: PP2A structural importance, regulation and its aberrant expression in cancer. Cancer Lett. 2013;335:9-18.

16. Guo S, Chen C, Ji F, Mao L, Xie Y. PP2A catalytic subunit silence by microRNA-429 activates AMPK and protects osteoblastic cells from dexamethasone. Biochem Biophys Res Commun. 2017;487:660-5.

17. Fowle H, Zhao Z, Grana X. PP2A holoenzymes, substrate specificity driving cellular functions and deregulation in cancer. Adv Cancer Res. 2019;144:55-93.

18. Palanichamy K, Kanji S, Gordon N, Thirumoorthy K, Jacob JR, Litzenberg KT, Patel D, Chakravarti A. NNMT silencing activates tumor suppressor PP2A, inactivates oncogenic STKs, and inhibits tumor forming ability. Clin Cancer Res. 2017;23:2325-34.

19. Rajala A, Wang Y, Abcouwer SF, Gardner TW, Rajala RVS. Developmental and light regulation of tumor suppressor protein PP2A in the retina. Oncotarget. 2018;9:1505-23.

20. Reynhout S, Janssens V. Physiologic functions of PP2A: lessons from genetically modified mice. Biochim Biophys Acta Mol Cell Res. 1866;2019:31-50.

21. Thompson JJ, Williams CS. Protein phosphatase 2A in the regulation of Wnt signaling, stem cells, and Cancer. Genes Basel. 2018;9.

22. Ross JA, Cheng H, Nagy ZS, Frost JA, Kirken RA. Protein Phosphatase 2A Regulates Interleukin-2 Receptor Complex Formation and JAK3/STAT5 Activation. J Biol Chem 285: 3582-3591.

23. Fukukawa C, Shima H, Tanuma N, Okada T, Kato N, Adachi Y, Kikuchi K. The oncoprotein I-2PP2A/SET negatively regulates the MEK/ERK pathway and cell proliferation. Int J Oncol. 2005;26:751-6.

24. Bae D, Ceryak S. Raf-independent, PP2A-dependent MEK activation in response to ERK silencing. Biochem Biophys Res Commun. 2009;385:523-7.

25. Raabe T, Rapp UR. Ras signaling: PP2A puts Ksr and Raf in the right place, Current Biology Cb; 13: 0-0.

26. Sieburth DS, Sundaram M, Howard RM, Han M. A PP2A regulatory subunit positively regulates Ras-mediated signaling during Caenorhabditis elegans vulval induction. Genes Dev. 1999;13:2562-9.

27. Zhang L, Zhou H, Li X, Vartuli RL, Rowse M, Xing Y, Rudra P, Ghosh D, Zhao $\mathrm{R}$, Ford HL. Eya3 partners with PP2A to induce c-Myc stabilization and tumor progression. Nat Commun. 2018;9.

28. Janghorban M, Farrell AS, Allen-Petersen BL, Pelz C, Daniel CJ, Oddo J, Langer EM, Christensen DJ, Sears RC. Targeting C-MYC by antagonizing PP2A inhibitors in breast cancer. Proc Natl Acad Sci U S A. 2014;111:9157-62.

29. Lee $\mathrm{M}, \mathrm{Ko} \mathrm{H}$, Yun M. Cancer metabolism as a mechanism of treatment resistance and potential therapeutic target in hepatocellular carcinoma. Yonsei Med J. 2018;59:1143-9.

30. Lopez Torrecilla J, Hervas A, Zapatero A, Gomez Caamano A, Macias V, Herruzo I, Maldonado X, Gomez Iturriaga A, Casas F, Gonzalez San Segundo C. Uroncor consensus statement: management of biochemical recurrence after radical radiotherapy for prostate cancer: from biochemical failure to castration resistance. Rep Pract Oncol Radiother. 2015;20:259-72.

31. Hong CS, Ho W, Zhang C, Yang C, Elder JB, Zhuang Z. LB100, a small molecule inhibitor of PP2A with potent chemo- and radio-sensitizing potential. Cancer Biol Ther. 2015;16:821-33.

32. Soprano KJ, Purev E, Vuocolo S, Soprano DR. Rb2/p130 and protein phosphatase 2A: key mediators of ovarian carcinoma cell growth suppression by all-trans retinoic acid. Oncogene. 2006;25:5315-25.

33. Qin S, Li J, Si Y, He Z, Zhang T, Wang D, Liu X, Guo Y, Zhang L, Li S, Li Q, Liu Y. Cucurbitacin B induces inhibitory effects via CIP2A/PP2A/Akt pathway in glioblastoma multiforme. Mol Carcinog. 2018;57:687-99.

34. Hein AL, Brandquist ND, Ouellette CY, Seshacharyulu P, Enke CA, Ouellette MM, Batra SK, Yan Y. PR55alpha regulatory subunit of PP2A inhibits the MOB1/LATS cascade and activates YAP in pancreatic cancer cells. Oncogenesis. 2019;8:63.

35. Stafman LL, Williams AP, Marayati R, Aye JM, Stewart JE, Mroczek-Musulman E, Beierle EA. PP2A activation alone and in combination with cisplatin decreases cell growth and tumor formation in human HuH6 hepatoblastoma cells. PLoS One. 2019;14:e0214469.

36. Lv P, Wang Y, Ma J, Wang Z, Li JL, Hong CS, Zhuang Z, Zeng YX. Inhibition of protein phosphatase $2 A$ with a small molecule LB100 radiosensitizes nasopharyngeal carcinoma xenografts by inducing mitotic catastrophe and blocking DNA damage repair. Oncotarget. 2014;5:7512-24.
37. Yang SH, Kuo TC, Wu H, Guo JC, Hsu C, Hsu CH, Tien YW, Yeh KH, Cheng AL, Kuo SH. Perspectives on the combination of radiotherapy and targeted therapy with DNA repair inhibitors in the treatment of pancreatic cancer. World J Gastroenterol. 2016;22:7275-88.

38. Hayward D, Bancroft J, Mangat D, Alfonso-Perez T, Dugdale S, McCarthy J, Barr FA, Gruneberg U. Checkpoint signaling and error correction require regulation of the MPS1 T-loop by PP2A-B56. J Cell Biol. 2019;218:3188-99.

39. Gharbi-Ayachi A, Labbe J-C, Burgess A, Vigneron S, Strub J-M, Brioudes E, VanDorsselaer A, Castro A, Lorca T. The Substrate of Greatwall Kinase, Arpp19, Controls Mitosis by Inhibiting Protein Phosphatase 2A. Science. 330:1673-7.

40. Jiangtao Y, Fleming SL, Byron W, Williams EV, Zexiao L, Patrizia S, Rieder CL, Goldberg ML. Greatwall kinase: a nuclear protein required for proper chromosome condensation and mitotic progression in Drosophila 2004; 164: 487.

41. Adhikari D, Diril MK, Busayavalasa K, Risal S, Nakagawa S, Lindkvist R, Shen Y, Coppola V, Tessarollo L, Kudo NR, Kaldis P, Liu K. Mastl is required for timely activation of APC/C in meiosis I and Cdk1 reactivation in meiosis II. J Cell Biol. 2014;206:843-53.

42. Naetar N, Soundarapandian V, Litovchick L, Goguen KL, Sablina AA, Bowman-Colin C, Sicinski P, Hahn WC, DeCaprio JA, Livingston DM. PP2Amediated regulation of Ras signaling in $\mathrm{G} 2$ is essential for stable quiescence and normal G1 length. Mol Cell. 2014;54:932-45.

43. Wang F, Zhu S, Fisher LA, Wang W, Oakley GG, Li C, Peng A. Protein interactomes of protein phosphatase 2A B55 regulatory subunits reveal B55mediated regulation of replication protein a under replication stress. Sci Rep. 2018;8:2683.

44. Kim SY, Hyun SY, Jang YJ. Dephosphorylation of PIk1 occurs through PP2AB55/ENSA/Greatwall pathway during mitotic DNA damage recovery. Cell Cycle. 2019;18:1154-67.

45. Nijenhuis W, Vallardi G, Teixeira A, Kops GJ, Saurin AT. Negative feedback at kinetochores underlies a responsive spindle checkpoint signal. Nat Cell Biol. 2014;16:1257-64.

46. Biau J, Chautard E, Verrelle P, Dutreix M. Altering DNA Repair to improve radiation therapy: specific and multiple pathway targeting. Front Oncol. 2019;9:1009

47. Kalsbeek D, Golsteyn RM. G2/M-phase checkpoint adaptation and micronuclei formation as mechanisms that contribute to genomic instability in human cells. Int J Mol Sci. 2017;18:2344.

48. Winters ZE. P53 pathways involving G2 checkpoint regulators and the role of their subcellular localisation. J R Coll Surg Edinb. 2002;47:591-8.

49. Yang J, Jing L, Liu CJ, Bai WW, Zhu SC. 53BP1 regulates cell cycle arrest in esophageal cancer model. Eur Rev Med Pharmacol Sci. 2019;23:604-12.

50. Guo J, Wu G, Bao J, Hao W, Lu J, Chen X. Cucurbitacin B induced ATMmediated DNA damage causes G2/M cell cycle arrest in a ROS-dependent manner. PLoS One. 2014;9.

51. Yan Y, Cao PT, Greer PM, Nagengast ES, Kolb RH, Mumby MC, Cowan KH. Protein phosphatase $2 \mathrm{~A}$ has an essential role in the activation of gammairradiation-induced G2/M checkpoint response. Oncogene. 2010;29:4317-29.

52. Zhu T, Matsuzawa S, Mizuno Y, Kamibayashi C, Mumby MC, Andjelkovic N, Hemmings BA, Onoe K, Kikuchi K. The interconversion of protein phosphatase 2A between PP2A1 and PP2A0 during retinoic acid-induced granulocytic differentiation and a modification on the catalytic subunit in $\mathrm{S}$ phase of HL-60 cells. Arch Biochem Biophys. 1997;339:210-7.

53. Kim LH, Hong ST, Choi KW. Protein phosphatase 2A interacts with Verthandi/Rad21 to regulate mitosis and organ development in Drosophila. Sci Rep. 2019;9:7624.

54. Pinto BS, Orr-Weaver TL. Drosophila protein phosphatases $2 A B^{\prime}$ Wdb and Wrd regulate meiotic centromere localization and function of the MEI-S332 Shugoshin. Proc Natl Acad Sci U S A. 2017;114:12988-93.

55. Cameron BD, Traver G, Roland JT, Brockman AA, Dean D, Johnson L, Boyd K Ihrie RA, Freeman ML. Bcl2-expressing quiescent type $B$ neural stem cells in the ventricular-subventricular zone are resistant to concurrent Temozolomide/X-irradiation. Stem Cells. 2019:37:1629-39.

56. Xiong Y, Lan J, Huang K, Zhang Y, Zheng L, Wang Y, Ye Q. PP2Ac upregulates PI3K-Akt signaling and induces hepatocyte apoptosis in liver donor after brain death. Apoptosis. 2019;24:921-33.

57. Pagano MA, Tibaldi E, Molino P, Frezzato F, Trimarco V, Facco M, Zagotto G, Ribaudo G, Leanza L, Peruzzo R, Szabo I, Visentin A, Frasson M, Semenzato G, Trentin L, Brunati AM. Mitochondrial apoptosis is induced by Alkoxy phenyl-1-propanone derivatives through PP2A-mediated dephosphorylation of bad and Foxo3A in CLL. Leukemia. 2019;33:1148-60. 
58. Huang B, Yang CS, Wojton J, Huang NJ, Chen C, Soderblom EJ, Zhang L, Kornbluth S. Metabolic control of Ca2+/calmodulin-dependent protein kinase II (CaMKII)-mediated caspase-2 suppression by the B55beta/protein phosphatase 2A (PP2A). J Biol Chem. 2014;289:35882-90.

59. Koma $\mathrm{Yl}$, Ito A, Watabe K, Kimura SH, Kitamura Y. A truncated isoform of the PP2A B56gamma regulatory subunit reduces irradiation-induced Mdm2 phosphorylation and could contribute to metastatic melanoma cell radioresistance. Histol Histopathol. 2004;19:391-400.

60. Azad A, Storey A. Chk1 activity is required for BAK multimerization in association with PUMA during mitochondrial apoptosis. Cell Communication and Signaling. 2014;12:42.

61. Ruvolo PP. A functional role for the B56 alpha -subunit of protein phosphatase $2 \mathrm{~A}$ in Ceramide-mediated regulation of $\mathrm{BCl} 2$ phosphorylation status and function. J Biol Chem. 2002;277:22847-52.

62. Dung TD, Day CH, Binh TV, Lin C-H, Hsu H-H, Su C-C, Lin Y-M, Tsai F-J, Kuo W-W, Chen L-M. PP2A mediates diosmin p53 activation to block HA22T cell proliferation and tumor growth in xenografted nude mice through PI3KAkt-MDM2 signaling suppression. Food Chem Toxicol 2012; 50: 0-1810.

63. Li HH, Cai X, Shouse GP, Piluso LG, Liu X. A specific PP2A regulatory subunit, B56gamma, mediates DNA damage-induced dephosphorylation of p53 at Thr55. EMBO J. 2007;26:402-11.

64. Jin Z, Wallace L, Harper SQ, Yang J. PP2A:B56?, a substrate of Caspase-3, regulates p53-dependent and p53-independent apoptosis during development. J Biol Chem. 2010;285:34493-502.

65. Park D-S, Yoon G-H, Lee H-S, Choi S-C. Capsaicin inhibits the Wnt/ß-catenin signaling pathway by down-regulating PP2A. Biochemical Biophysical Research Communications. 2016:478:455-61.

66. Ashrafizadeh M, Ahmadi Z, Farkhondeh T, Samarghandian S. Resveratrol targeting the Wnt signaling pathway: a focus on therapeutic activities. J Cell Physiol. 2019 Oct 21. https://doi.org/10.1002/jcp.29327 [Epub ahead of print].

67. Kleszcz R. The canonical Wnt pathway. Postepy Biochem. 2019;65:183-92.

68. Ratcliffe MJ, Itoh K, Sokol SY. A positive role for the PP2A catalytic subunit in Wht signal transduction. J Biol Chem. 2000;275:35680-3.

69. Bos CL, Kodach LL, van den Brink GR, Diks SH, van Santen MM, Richel DJ, Peppelenbosch MP, Hardwick JC. Effect of aspirin on the Wnt/beta-catenin pathway is mediated via protein phosphatase 2A. Oncogene. 2006;25:6447-56.

70. Wu MY, Xie X, Xu ZK, Xie L, Chen Z, Shou LM, Gong FR, Xie YF, Li W, Tao M. PP2A inhibitors suppress migration and growth of PANC-1 pancreatic cancer cells through inhibition on the Wnt/beta-catenin pathway by phosphorylation and degradation of beta-catenin. Oncol Rep. 2014;32:513-22.

71. Dong L, Zhu J, Wen $X$, Jiang T, Chen Y. Involvement of SET in the Wnt signaling pathway and the development of human colorectal cancer. Oncol Lett. 2014;7:1203-8.

72. Estévez MD, Vieytes MR, Louzao MC, Botana LM. Effect of okadaic acid on immunologic and non-immunologic histamine release in rat mast cells. Biochem Pharmacol. 1994;47:591-3.

73. Hu C, Yu M, Ren Y, Li K, Maggio DM, Mei C, Ye L, Wei J, Jin J, Zhuang Z, Tong H. PP2A inhibition from LB100 therapy enhances daunorubicin cytotoxicity in secondary acute myeloid leukemia via miR-181b-1 upregulation. Sci Rep. 2017;7:15260

74. Ho WS, Feldman MJ, Maric D, Amable L, Heiss JD. PP2A inhibition with LB100 enhances cisplatin cytotoxicity and overcomes cisplatin resistance in medulloblastoma cells. Oncotarget. 2016;7:12447-63.

75. Wei D, Parsels LA, Karnak D, Davis MA, Parsels JD, Marsh AC, Zhao L, Maybaum J, Lawrence TS, Sun Y. Inhibition of protein phosphatase 2A Radiosensitizes pancreatic cancers by modulating CDC25C/CDK1 and homologous recombination repair. Clin Cancer Res Official J Am Assoc Cancer Res. 2013;19:4422-32.

76. De Angelis ML, Francescangeli F, Zeuner A. Breast Cancer stem cells as drivers of tumor Chemoresistance, dormancy and relapse: new challenges and therapeutic opportunities. Cancers Basel. 2019;11:1569.

77. Zhang D, Fu M, Li L, Ye H, Song Z, Piao Y. PKC-delta attenuates the cancer stem cell among squamous cell carcinoma cells through down-regulating p63. Pathol Res Pract. 2017;213:1119-24.

78. Lu J, Zhuang Z, Song DK, Mehta GU, Ikejiri B, Mushlin H, Park DM, Lonser RR. The effect of a PP2A inhibitor on the nuclear receptor corepressor pathway in glioma. J Neurosurg. 2010;113:225-33.

79. Hiramatsu H, Kobayashi K, Kobayashi K, Haraguchi T, Ino Y, Todo T, Iba H. The role of the SWI/SNF chromatin remodeling complex in maintaining the stemness of glioma initiating cells. Sci Rep. 2018;7:889.
80. Sudoh S, Kawakami H, Ohta M, Nakamura S. Ciliary neurotrophic factor induced-increase in beta-amyloid precursor protein mRNA in rat C6 glioma cells. Biochem Biophys Res Commun. 1994;204:391-8.

81. Li XF, Li SY, Dai CM, Li JC, Huang DR, Wang JY. PP2A inhibition by LB-100 protects retinal pigment epithelium cells from UV radiation via activation of AMPK signaling. Biochem Biophys Res Commun. 2018;506:73-80.

82. Huang CY, Hung MH, Shih CT, Hsieh FS, Kuo CW, Tsai MH, Chang SS, Hsiao YJ, Chen LJ, Chao TI, Chen KF. Antagonizing SET Augments the effects of radiation therapy in hepatocellular carcinoma through reactivation of PP2Amediated Akt Downregulation. J Pharmacol Exp Ther 2018; 366: 410-421.

83. Ho WSC, Sizdahkhani S, Hao S, Song H, Seldomridge A, Tandle A, Maric D, Kramp T, Lu R, Heiss JD. LB-100, a novel protein phosphatase 2A (PP2A) inhibitor, sensitizes malignant meningioma cells to the therapeutic effects of radiation. Cancer Lett. 2018;415:217-26.

84. Miao J, Shi R, Li L, Chen F, Zhou Y, Tung YC, Hu W, Gong CX, lqbal K, Liu F. Pathological tau from Alzheimer's brain induces site-specific hyperphosphorylation and SDS- and reducing agent-resistant aggregation of tau in vivo. Front Aging Neurosci. 2019;11:34.

85. Lai D, Chen M, Su J, Liu X, Rothe K, Hu K, Forrest DL, Eaves CJ, Morin GB, Jiang $X$. Response to comment on "PP2A inhibition sensitizes cancer stem cells to $A B L$ tyrosine kinase inhibitors in $B C R-A B L(+)$ human leukemia". Sci Transl Med. 2019;11:eaav0819.

86. Yu CQ, Yin LQ, Tu ZT, Liu DW, Luo WP. The regulatory role of dopamine receptor D1 on PP2A via SUMO-1 modification. Eur Rev Med Pharmacol Sci. 2017;21:3270-6.

87. Liu L, Huang Z, Chen J, Wang J, Wang S. Protein phosphatase 2A mediates JS-K-induced apoptosis by affecting BCl-2 family proteins in human hepatocellular carcinoma HepG2 cells. J Cell Biochem. 2018;119:6633-43.

88. Deng X, Gao F, May WS. Protein phosphatase 2A inactivates Bcl2's antiapoptotic function by dephosphorylation and up-regulation of Bcl2-p53 binding. Blood. 2009;113:422-8.

\section{Publisher's Note}

Springer Nature remains neutral with regard to jurisdictional claims in published maps and institutional affiliations.

\section{Ready to submit your research? Choose BMC and benefit from:}

- fast, convenient online submission

- thorough peer review by experienced researchers in your field

- rapid publication on acceptance

- support for research data, including large and complex data types

- gold Open Access which fosters wider collaboration and increased citations

- maximum visibility for your research: over $100 \mathrm{M}$ website views per year

At BMC, research is always in progress.

Learn more biomedcentral.com/submissions 